\title{
EVALUATION OF NEW APPLE CULTIVARS GROWN INROMANIAN NORTHEASTERN AREA
}

\author{
M. Corneanu1 ${ }^{1}$, S. Sîrbu ${ }^{1 *}$, E. Iurea1 ${ }^{1}$ I. Mineață ${ }^{1}$ and I.E. Golache ${ }^{1}$
}

1Research and Development Station for Fruit Growing Iași, Romania.

*Corresponding author email: sorinas66@yahoo.com

\begin{abstract}
The paper presents a 2-years study of the valuable characteristics in four foreign apple cultivars grown in northeastern Romania, named Moldavia area. The phenological stages, quality traits of fruits and some chemical parameters were evaluated. Start flowering was determined at April 17th ('Resse'), while end of flowering was identified the period April $27^{\text {th }}-28^{\text {th }}$. Period of flowering was 9 to 12 days as average for studied years 2019-2020. Fruit's weight have varied between $120.55 \mathrm{~g}$ ('Resse') and $179.46 \mathrm{~g}$ ('Remo'), while fruit's equatorial diameter have varied between $65.82 \mathrm{~mm}$ and $74.87 \mathrm{~mm}$ at 'Resse' and respectively 'Remo', but no statistically distinct differences registered between all studied apple cultivars. The values of the soluble dry solids range between $14.65^{\circ}$ Brix ('Resse') to $17.05^{\circ} \mathrm{Brix}$ ('Relinda'), and the total dry solids has recorded values between $17.95 \%$ ('Resse') to 21.39\% ('Remo'). The studied apple cultivars showed variability but some got remarked through large fruit's size or high level of soluble dry solids.
\end{abstract}

\section{INTRODUCTION}

Apple tree growing is one of the most known and widespread crops in the temperate climates of the globe. The variability of the genus and the main species of Malus domestica, favors dissemination and adaptation to various geographical areas (Grădinariu, 2002). Worldwide, approximately 5 million hectares are occupied by apple cultivation providing a total production of 84 million tonnes (FAO, 2020). The share of apple cultivation in the world economy of fruit production is mainly due to the role that fruits have in the rational human diet. They are consumed fresh or processed as alcoholic or non-alcoholic beverages (juices or nectars). In Romania, applestree growing occupies the leading place in fruit production. According to statistical data of the Ministry of Agriculture and Rural Development of Romania, the area cultivated with this species is about 54 thousand hectares, while the total production of apples in Romania can reach 644 thousand tons (Brodeală et al., 2020). For apple growers, fruit size is strongly correlated with profits, but shape and color are also some of the most important qualities for fruit consumers (Schotzko, 1985). Zajmi et al. (2007) show that in practice there are several methods for determining the maturity of the fruit according to market requirements, both for consumers and the processing sector. In practice, the following methods are mainly used: the number of days from pollination to fruit harvest, the separation of the branch stalk, the change of fruit color, the change of seed color, etc. There are also methods of physiological analysis, such as the spectrophotometric method or the determination of the presence of starch (Lepaja K. et al., 2014). According to Shqahu (2007), apple is a culture that grow well on a wide range of soils, both in texture and soil type. It has moderate demands on temperature, giving good results in areas where the average annual temperature is between 8 and $9.5^{\circ} \mathrm{C}$, but can 
grow and develop in regions with average temperatures of $7.5-7.9^{\circ} \mathrm{C}$. The studied apple cultivars showed high variability but some got remarked through large fruit's size or high level of soluble dry substance.

\section{MATERIALS AND METHODS}

The research was performed between 2019-2020, at Research and Delopment Station for Fruit Growing (RSFG) Iași, using as research material four apple cultivars: 'Golden Reinders', originating from Netherland (Militaru et al., 2018) and 'Remo', 'Relinda' and 'Resse', originating from Germany (Hanke et al.,2017), grafted on MM106. The experimental field is located in the Sârca valley, where the annual average temperature was $11.33^{\circ} \mathrm{C}$ in 2019 and $12.03^{\circ} \mathrm{C}$ in the first seven months of 2020 while the multiannual average being $11.68^{\circ} \mathrm{C}$. The trees were planted at $2 \times 4 \mathrm{~m}$ distances and led under the shape ofpalmette. On the tree rows, the soil was prepared with the rotary orchard tiller and between the rows, the soil was grassed. The control of diseases and pests was performed according to the received warnings, phytosanitary treatments being applied. To appreciate the flowering and fructification phenophases the Fleckinger system was used (1960). Biometric measurements and determinations were performed as follows:fruit's equatorial diameter $(\mathrm{mm})$, thicknes (mm) and lenght (mm) using slide gauge tool Lumytools (Radu et al., 1957) and its average weight (g) using an analytical balance Radwag. The chemical determinations included for the analysis: the soluble dry solids (SDS\%) using a Zeiss refractometer,the determination of the humidity (\%) and of the total dry substance (TDS\%) using the oven for five hours to $105^{\circ} \mathrm{C}$ (Cociu, 1989). The experimental data was interpreted statistically by analysing the variance.

\section{RESULTS AND DISCUSSIONS}

The main fructification phenophases of studied apple cultivars are presented in table 1. Bud burst start on $4^{\text {th }}$ of April at 'Remo' cv.,but were end on $6^{\text {th }}$ of April at 'Relinda' cv. Flowering beginning was between $17^{\text {th }}$ to $19^{\text {th }}$ of April, and blooming ending was between $27^{\text {th }}$ to $28^{\text {th }}$ of April. Bloom period of studied apple cultivars was between 9 to 12 days.

Table 1. The main fructification phenophases of studied apple cultivars

(RSFG Iași, 2019-2020)

$\begin{array}{cccccc}\text { Cultivars } & \begin{array}{c}\text { Bud burst } \\ \text { (data) }\end{array} & \begin{array}{c}\text { Flowering } \\ \text { beginning (data) }\end{array} & \begin{array}{c}\text { Flowering } \\ \text { ending (data) }\end{array} & \begin{array}{c}\text { Duration } \\ \text { period } \\ \text { (days) }\end{array} & \begin{array}{c}\text { Ripening } \\ \text { time (data) }\end{array} \\ \begin{array}{c}\text { Golden Reinders } \\ \text { Remo }\end{array} & \text { April 5 } & \text { April 18 } & \text { April 28 } & 11 & \text { September 9 } \\ \text { Relinda } & \text { April 6 } & \text { April 19 } & \text { April 27 } & 9 & \text { September 4 } \\ \text { Resse } & \text { April 5 } & \text { April 19 } & \text { April 28 } & 10 & \text { September 8 } \\ & & \text { April 28 } & 12 & \text { September 4 }\end{array}$

In order to establish the adaptability of the studied cultivars to the ecological conditions in Iași-Romania, biometric determinations as: weight, diameter and height of the fruits were recorded. Thus, were made centralized averages of the obtained values (Table 2 ). Through the statistical interpretation of the results compared to the average as control, were obtained insignificant differences for all four cultivars. But we finded that the greatest fruit's weight registered 'Remo' and 'Relinda' cvs.with $179.46 \mathrm{~g}$ and $168.46 \mathrm{~g}$, respectively.

Regarding the weight of the fruit, the largest differences from the control variant were recorded at 'Resse'cv., with a lower value by 33.5 g (Table 2). However, Zadravec et al. (2013) showed that fruit diameter and fruit weightare positively correlated. 
The fruit's lenght and thickness of the studied four apple cultivars did not have significant differences compared with average as control (Table 2).

Table 2. Physical features of the fruit in the investigated apple cultivars

(RSFG Iași, 2019-2020)

\begin{tabular}{|c|c|c|c|c|}
\hline Cultivar & Fruit's weight(g) & $\begin{array}{c}\text { Fruit's equatorial } \\
\text { diameter(mm) }\end{array}$ & $\begin{array}{c}\text { Fruit's } \\
\text { thickness(mm) }\end{array}$ & $\begin{array}{c}\text { Fruit's } \\
\text { length(mm) }\end{array}$ \\
\hline Golden Reinders & $147.67^{\mathrm{ns}}$ & $71.33^{\mathrm{ns}}$ & $70.03^{\mathrm{ns}}$ & $63.20^{\mathrm{ns}}$ \\
\hline Resse & $120.55^{\mathrm{ns}}$ & $65.82^{\mathrm{ns}}$ & $63.37^{\mathrm{ns}}$ & $56.02^{\mathrm{ns}}$ \\
\hline Remo & $179.46^{\mathrm{ns}}$ & $74.87^{\mathrm{ns}}$ & $72.84^{\mathrm{ns}}$ & $66.26^{\mathrm{ns}}$ \\
\hline Relinda & $168.46^{\mathrm{ns}}$ & $73.45^{\mathrm{ns}}$ & $69.88^{\mathrm{ns}}$ & $65.83^{\mathrm{ns}}$ \\
\hline Average (control) & 154.03 & 71.37 & 69.03 & 62.83 \\
\hline DL 5\% & 97.13 & 14.06 & 13.05 & 13.74 \\
\hline DL 1\% & 141.28 & 20.46 & 18.98 & 19.98 \\
\hline DL 0.1\% & 211.93 & 30.68 & 28.48 & 29.98 \\
\hline
\end{tabular}

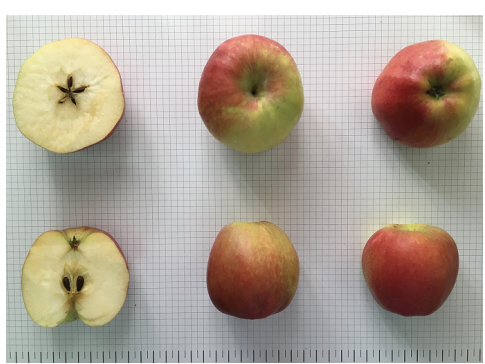

Figure. 1. Relindaapplecv. (photo Iulia Mineata)

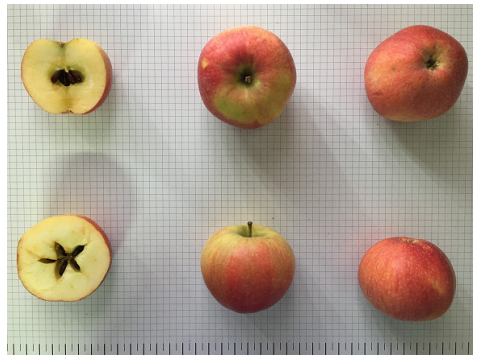

Figure 2. Remoapplecv. (photo Iulia Mineata)

The average soluble dry solids of the studied four apple cultivars was between 14.65\% ('Resse') and 17.05\% ('Relinda'). By statistically interpreting distinctly significant differences were recorded for 'Relinda'cv. and negative distinctly significant differences for 'Resse'cv. There were no significant differences in the 'Golden Reinders' and 'Remo'cvs. compared with average as control (Table 3).

Table 3. Chemical characteristics of the fruits in the investigated apple cultivars

(RSFG Iași, 2019-2020)

\begin{tabular}{|c|c|c|c|}
\hline Cultivar & SDS(\%) & TDS(\%) & Humidity(\%) \\
\hline Golden Reinders & $15.90^{\mathrm{ns}}$ & $19.01^{\mathrm{ns}}$ & $80.98^{\mathrm{ns}}$ \\
\hline Resse & $14.65^{00}$ & $18.96^{\mathrm{ns}}$ & $81.03^{\mathrm{ns}}$ \\
\hline Remo & $15.68^{\mathrm{ns}}$ & $21.39^{* *}$ & $78.61^{00}$ \\
\hline Relinda & $17.05^{* *}$ & $17.95^{0}$ & $82.04^{*}$ \\
\hline Average (control) & 15.82 & 19.33 & 80.66 \\
\hline DL 5\% & 0.64 & 1.53 & 1.53 \\
\hline DL 1\% & 0.93 & 2.22 & 2.22 \\
\hline DL 0.1\% & 1.41 & 3.33 & 3.33 \\
\hline
\end{tabular}

The analyses performed to determine the humidity and total dry solids had insignificant differences of 'Golden Reinders' and 'Resse'cvs. compared to the average as 
control. The difference from the average of total dry solids in 'Remo'cv. is distinctly significant, while 'Relinda' variety shows negatively significant differences. The humidity of the fruit's showed significant differences in 'Relinda'cv. and negative distinctly significant differences in 'Remo'cv. However, our results are according with other similar research on apple genotypes. Also, Campeanu et al., (2009) find that TDS recording values between $11.63 \%$ to $21.31 \%$, while SDS recording values between $11.00 \%$ to $15.50 \%$ at ten apple genotypes in Romanian climate conditions.

\section{CONCLUSIONS}

- The research shows results that have an impact on the technology of apple growing, both for fresh consumation and for processing, by using foreign cultivars of apple in the climatic region of North-East Romania, the Iași area.

- All the quality parameters observed on the fruits, such as the diameter, the height, the weight and the content of the soluble dry substance demonstrate that 'Golden Reinders', 'Resse', 'Remo' and 'Relinda' cvs. have a good adaptability in the ecological conditions in Iași, keeping the characteristics specific to the cultivar.

\section{ACKNOWLEDGEMENTS}

This work was financially supported by the Romanian Academy of Agricultural and Forestry Sciences, Grant No. PT 1.4.4., with title 'Zonation and microzonation of varieties and rootstocks of apple, pear and quince tree species'.

\section{REFERENCES}

1. Brodeală A.M., Crăciun V., Căruțașu M., Brana M. and Petruș D. (2020). Producția vegetală la principalele culturi, INS, pp.12-14.

2. Campeanu G., Neata G. and Darjanschi G. (2009). Chemical Composition of the Fruits of Several Apple Cultivars Growth as Biological Crop. Not. Bot. Hort. Agrobot. Cluj 37 (2): 161-164.

3. Cociu V.andOprea Ș.(1989). Metode de cercetare în ameliorarea plantelor pomicole, Ed. Dacia, Cluj-Napoca, $208 \mathrm{pp}$.

4. Grădinariu G. (2002). Pomicultură specială, Ed. Ion Ionescu de la Brad, Iași, pp. 304.

5. Hanke M.V., Nachtigall G., Flachowsky H., Höfer M., Peil A. and Schuster M. (2017). Pillnitzer Obstsorten\&Obstunterlagen, pp. 100.

6. Kask K., Jänes H., Libek A., Arus L., Kikas A., Kaldmäe H., Univer N. and Univer T. (2010). New cultivars and future perspectives in professional fruit breeding in Estonia, Agronomy Research 8: 603-614.

7. Lepaja K., Kullaj E., Lepaja L., Avdiu V., Krasniqi N. andZajmi R. (2014). Fruit quality parameters of three apple cultivars in western Kosovo, 49th Croatian \& 9th International Symposium on Agriculture, Dubrovnik, Croatia, p. 690-693.

8. Militaru M., Coman M., Butac M., Sturzeanu M., Tititrică I., Călinescu M., Stanciu C., Botu M., Gavăț C., Sîrbu S., Iurea E., Erculescu M. and Sestraș A. (2018). Fondul de germoplasmă la speciile pomicole cultivate în România, Ed. Invel, pp. 210.

9. Radu I.F., Pandele I. and Enăchescu G. (1957). Proprietățile fizice, chimice și tehnologice ale fructelor principalelor specii pomicole cultivate în R.P.R. București: Edit. Acad. R. P. Române, pp.256

10. Schotzko T. (1985). Fruit size.The money maker. Proc. Hort. Ass. Wash. State Annual Meeting. Washington, 81: 92-96.

11. Shqahu V. (2007). Enciklopedi e kopshtarisë. Botimet Toena. Tiranë. pp.450

12. Zajmi A., Sylanaj S. and Berisha B. (2007).Pemëtaria praktike.USAID-KCBC.Prishtinë.165-167.

13. Zadravec P., Veberic R., Stampar F., Eler K. and Schmitzer V. (2013). Fruit size prediction of four apple cultivars: Accuracy and timing, Scientia Horticulturae, 160:177-181, https://doi.org/10.1016/j.scienta.2013.05.046.

14. http://www.fao.org/faostat/en/\#data/QC, 08.10.2020

15. https://www.madr.ro/.horticultura/fructe-si-legume.html 09. 10.2020 